\title{
PEMBUATAN DAN KARAKTERISASI PLASTIK BIODEGRADABLE DARI LIMBAH POLIPROPILENA DAN PATI BIJI DURIAN DENGAN PENAMBAHAN MALEAT ANHIDRIDA SEBAGAI AGEN PENGIKAT SILANG
}

\author{
Tengku Rachmi Hidayani, Elda Pelita, dan Dyah Nirmala \\ Politeknik ATI Padang, Jalan Bungo Pasang Tabing Padang 25171 \\ E-mail : rachmihidayani@yahoo.com
}

Received: 19 Desember 2016; revised: 26 Februari 2017; accepted: 31 Maret 2017

\begin{abstract}
ABSTRAK
PEMBUATAN DAN KARAKTERISASI PLASTIK BIODEGRADABLE DARI LIMBAH POLIPROPILENA DAN PATI BIJI DURIAN DENGAN PENAMBAHAN MALEAT ANHIDRIDA SEBAGAI AGEN PENGIKAT SILANG.

Penelitian dilakukan untuk menghasilkan plastik biodegradable dari pencampuran limbah polipropilena dan pati biji durian dengan menambahkan maleat anhidrida sebagai agen pengikat silang dan benzoil peroksida sebagai inisiator. Plastik polipropilena yang digunakan bersumber dari limbah plastik polipropilena yang ada di pasaran dikenal sebagai plastik gula. Pati biji durian didapatkan dengan metode perendaman dengan air sadah dan pengendapan dengan akuades. Pada penelitian ini, dilakukan dengan berbagai variasi bahan yang ditambahkan dengan perbandingan tertentu yaitu berturut-turut limbah polipropilena, pati biji durian, maleat anhidrida, dan benzoil peroksida yaitu (94:6:1), (94:6:1:1), (94:6:2:1), dan (94:6:3:1). Metode pencetakan plastik biodegradable dilakukan dengan metode kempa tekan. Plastik biodegradable dikarakterisasi dengan analisis sifat mekanik berupa uji tarik dengan menggunakan acuan standar ASTM D - 1822 type L, analisis biodegradable menggunakan metode gravimetri berdasarkan penurunan masa plastik setelah penanaman selama 1 bulan, dan analisis gugus fungsi dengan uji Fourier Transform Infra Red (FTIR). Dari hasil penelitian didapatkan kondisi optimum plastik biodegradable yang dihasilkan pada perbandingan limbah polipropilena, pati biji durian, maleat anhidrida, dan benzoil peroksida adalah (94:6:1:1) dengan nilai kekuatan tarik $9,81 \mathrm{~N} / \mathrm{m}^{2}$ dan kemuluran $0,5625 \%$, penurunan masa dari analisis uji biodegradable sebesar $9,08 \%$, dan interaksi kimia dari plastik biodegradable yang dihasilkan dapat dilihat berdasarkan hasil analisis dengan FTIR ditemukan bilangan gelombang yang menunjukkan gugus fungsi yang khas untuk menunjukkan ikatan antara limbah plastik polipropilena yang dicangkok dengan maleat anhidrida dengan bantuan inisiator benzoil peroksida dan pati biji durian.
\end{abstract}

Kata kunci : Plastik biodegradable, Limbah plastik polipropilena, Polipropilena, Polipropilena-g-MA, Pati

\begin{abstract}
PREPARATION AND CHARACTERIZATION OF BIODEGRADABLE PLASTIC FROM WASTE POLYPROPYLENE AND DURIAN SEED STARCH WITH MALEIC ANHYDRIDE AS CROSSLINKING AGENT ADDITION. The study was conducted to produce biodegradable plastics from polypropylene waste mixed with durian seeds starch using maleic anhydride as a crosslinking agent and benzoyl peroxide as an initiator. The polypropylene waste was obtained in the market known as the sugar plastic. Starch from the durian seed was obtained by soaking the durian seeds with water through precipitation method. In this study, the biodegradable plastic compositions were varied at certain ratio of polypropylene waste, starch from durian seeds, maleic anhydride, and benzoyl peroxide, namely (94: 6: 1), (94: 6: 1: 1), (94: 6: 2: 1), and (94: 6: 3 : 1). The biodegradability of the plastics was characterized through mechanical properties (ASTM D - 1822 type L), gravimetric method based on reduction of plastics period after planting for 1 month, and functional groups using Fourier Transform Infrared (FTIR) test. The results showed that the optimum conditions of biodegradable plastics waste occurred in the composition of (94: 6: 1: 1) with a tensile strength of $9.81 \mathrm{~N} / \mathrm{m}^{2}$ and elongation $0.5625 \%$, a decrease in future of test analysis biodegradable at $9.08 \%$. Chemical interactions of biodegradable plastics examined using FTIR revealed a wave number that showed typical functional groups with the bond between the polypropylene waste grafting with maleic anhydride with the aid of benzoyl peroxide initiator and starch durian seeds.
\end{abstract}

Key words: Plastics biodegradable, Polypropylene waste, Polypropylene, Polipropylene-g-MA, Starch 


\section{PENDAHULUAN}

Plastik biodegradable yang mengandung pati/amilum dapat didegradasi oleh bakteri pseudomonas dan bacillus yang memutus rantai polimer menjadi monomer-monomernya (Kaplan et al. 2004). Senyawa-senyawa hasil degradasi polimer selain menghasilkan karbondioksida dan air, juga menghasilkan senyawa organik lain yaitu asam organik dan aldehida yang tidak berbahaya bagi lingkungan. Plastik berbahan dasar pati/amilum aman bagi lingkungan. Sebagai perbandingan, plastik tradisional membutuhkan waktu sekitar 50 tahun agar dapat terdekomposisi alam, sementara plastik dengan kandungan pati/amilum dapat terdekomposisi 10 sampai dengan 20 kali lebih cepat dibandingkan dengan plastik konvensional yang ada. Hasil degradasi plastik ini dapat digunakan sebagai makanan hewan ternak atau sebagai pupuk kompos (Yuniarti 2010).

Adanya penumpukan limbah plastik polipropilena di alam, maka pada penelitian ini limbah polipropilena dipilih sebagai matriks, serta memiliki keunggulan harganya yang murah dan memiliki sifat spesifik yang berkualitas tinggi, dan besarnya jumlah limbah polipropilena di alam (Latief 2011). Pati merupakan polimer alami yang bersifat biodegradable. Dengan menambahkan pati ke dalam polimer sintesis maka diharapkan plastik yang dihasilkan dapat terdegradasi secara alami. Plastik biodegradable berbahan dasar pati dapat didegradasi oleh bakteri dengan cara memutus rantai polimer menjadi monomer-monomernya.

Pati dapat diperoleh dengan cara mengekstrak dari bagian beberapa tanaman seperti akar, umbi, batang, dan biji-bijian (Khoramnejadian 2013). Penelitian tentang pembuatan plastik biodegradable telah dilakukan dengan menggunakan pati dari berbagai tumbuhan diantaranya buah pisang dengan hasil maksimum yaitu dengan penambahan pati pisang sebanyak 2 gram dengan degradability 0,007 mg/hari (Ningsih 2012), kulit singkong dengan variasi maksimum 7:3 dengan bahan polimernya dengan penurunan masa 0,09 mg/hari (Yuniarti 2010).

Salah satu sumber pati yang ada saat ini adalah biji durian. Biji durian saat ini belum dapat dimanfaatkan secara luas. Setiap $100 \mathrm{~g}$ biji durian mengandung $51 \mathrm{~g}$ air; 46,2 g karbohidrat; 2,5 g protein; dan 0,2 g lemak. Kadar karbohidrat biji durian ini lebih tinggi dibandingkan dengan singkong $34,7 \%$ maupun ubi jalar $27,9 \%$. Kandungan karbohidrat yang tinggi ini memungkinkan pemanfaatan biji durian sebagai bahan pengganti sumber karbohidrat yang ada dalam bentuk tepung (Djaeni dan Prasetyaningrum 2010). Isolasi pati biji durian telah dilakukan dengan cara pembuangan kulit ari biji durian yang kemudian dilanjutkan dengan perendaman dengan kapur sirih dan penghancuran menjadi tepung pati dengan persen rendemen 30\% (Ummah 2013).

Nirmala et al. (2014) telah melakukan penelitian dengan mencampurkan limbah plastik polipropilena dengan pati biji durian, dengan berbagai variasi komposisi massa, dimana diperoleh hasil yang optimum antara limbah plastik polipropilena dengan pati biji durian pada perbandingan 94:6 yang memiliki kekuatan tarik $25,722 \mathrm{~N} / \mathrm{m}^{2}$ dan nilai perpanjangan putus $5,292 \%$, namun campuran limbah plastik polipropilena dengan pati biji durian tidak homogen. Penelitian pencampuran limbah plastik dengan pati biji durian telah dilakukan Hidayani et al. (2015) tanpa penambahan agen pengikat, terlihat adanya interaksi fisika yang terjadi antara limbah plastik polipropilena dan pati biji durian, namun interaksi kimia tidak terlihat. Hal ini kemungkinan terjadi karena polipropilena memiliki sifat yang sulit berikatan dengan zat lain karena gugus ujungnya tertutup untuk gugus lain, yang mengakibatkan diharuskannya melakukan modifikasi terhadap polipropilena agar mendapatkan adanya interaksi kimia yang diharapkan dapat membantu mempercepat proses biodegradasi (Ningsih 2012). Untuk mengatasi hal tersebut, perlu dilakukan fungsionalisasi polipropilena dengan melakukan suatu reaksi grafting dengan suatu monomer tak jenuh seperti contohnya maleat anhidrida (MA), asam akrilat dan berbagai turunannya, dengan menambahkan peroksida sebagai bahan inisiator (Inggaweni dan Suyatno 2015).

Fungsionalisasi polipropilena dengan maleat anhidrida dilakukan dengan inisiator benzoil peroksida untuk memotong rantai panjang polipropilena. Grafting maleat anhidrida ke dalam campuran tersebut bertujuan untuk menghasilkan polipropilena dengan berat molekul lebih rendah dan tingkat kepolarannya meningkat. Perbandingan optimum penambahan maleat anhidrida adalah sebanyak $2 \%$ dan inisiator benzoil peroksida sebanyak $1 \%$ (Hidayani 2012).

Berkaitan dengan proses grafting, Matondang (2013) telah melakukan penelitian interaksi kimia dari pati sagu kelapa sawit dengan polipropilena grafting dengan maleat anhidrida. Metode ekstraksi pati perendaman dengan air sadah dan pengendapan dengan air. Pencampuran pati dengan bahan plastik berkisar antara $0,5 \%$ sampai dengan $4 \%$ dari berat plastik biodegradable yang dihasilkan dengan sifat mekanis yang paling maksimum dimana harga tensile strength $16,010 \mathrm{~N} / \mathrm{m}^{2}$ dan elongation at break $8,5937 \%$. Jumlah pati dari kelapa sawit kecil, maka dibutuhkan sumber pati dari bahan lain. 
Dalam penelitian ini, dilakukan suatu penelitian pembuatan plastik biodegradable dari limbah plastik polipropilena dengan pati biji durian dengan penambahan maleat anhidrida dan benzoil peroksida sebagai agen pengikat silang. Ekstraksi pati biji durian menggunakan metode perendaman dengan kapur sirih dan pengendapan dengan air, serta proses pencetakan plastik biodegradable dengan metode kempa tekan (hot press). Hasil plastik dilakukan karakterisasi dengan analisis sifat mekanik dengan uji tarik dan kemuluran, analisis kemampuan terurai dengan uji biodegradable, dan analisis gugus fungsi dengan $F T$-IR secara detail.

\section{BAHAN DAN METODE}

\section{Bahan}

Bahan yang digunakan dalam penelitian ini adalah limbah polipropilena dari limbah kantong plastik gula, pelarut xilena, metanol, aseton, benzoil peroksida, maleat anhidrida, biji durian, dan air.

Peralatan yang digunakan dalam penelitian ini adalah neraca analitis dengan merk Mettler Toledo (range 4 desimal, maksimal $500 \mathrm{~g}$ ), labu refluks ukuran $500 \mathrm{~mL}$ merk Pyrex, magnetic stirer, alat pemanas stirer merk PMC, pendingin Liebig merk Pyrex, oven listrik merk Memmert, alat cetak tekan merk Torsee SC2DE, alat-alat gelas merk Pyrex, seperangkat alat uji tarik type SC-2DE CAP $2000 \mathrm{kgf}$ kapasitas $1 \mathrm{~kg}$ pada range suhu $80{ }^{\circ} \mathrm{C}$ sampai dengan $350{ }^{\circ} \mathrm{C}$, termometer raksa $10^{\circ} \mathrm{C}$ sampai dengan $400{ }^{\circ} \mathrm{C}$, blender merk National, ayakan 140 mesh merk Tantalum 3N8 Purity, dan seperangkat alat Fourier Transform Infrared Spectroscopy (FT-IR) Shimadzu IRAffinity-1S.

\section{Metode}

Penelitian ini bersifat eksperimental laboratorium yang dilakukan dalam beberapa tahapan.

Tahapan pertama, dilakukan pengambilan pati biji durian dangan cara membersihkan biji durian dari kotorannya dan membuang kulit ari biji durian yang berwarna coklat. Setelah biji durian bersih dari kulit ari, biji durian direndam dengan air kapur sirih selama 1 jam kemudian dicuci bersih. Biji durian dihaluskan dengan menggunakan blender dan diberi air kemudian disaring. Hasil saringan diendapkan selama 1 malam, kemudian pati dipisahkan dan dikeringkan.

Tahapan kedua adalah grafting maleat anhidrida dengan inisiator benzoil peroksida dengan limbah plastik polipropilena menggunakan metode refluks dengan pelarut xilena dan penambahan pati biji durian dengan beberapa perbandingan yaitu limbah plastik polipropilena (100), limbah polipropilena dan pati biji durian (94:6), limbah polipropilena, pati biji durian, maleat anhidrida (94:6:1), limbah polipropilena, pati biji durian, maleat anhidrida, benzoil peroksida (94:6:1:1), limbah polipropilena, pati biji durian, maleat anhidrida, benzoil peroksida (94:6:2:1), dan limbah polipropilena, pati biji durian, maleat anhidrida, benzoil peroksida (94:6:3:1). Masing-masing perbandingan dibuat dalam komposisi $10 \mathrm{~g}$.

Tahapan ketiga adalah pencetakkan campuran pati biji durian dengan serbuk limbah plastik polipropilena yang telah dilakukan grafting dengan maleat anhidrida dengan inisiator benzoil peroksida dengan metode press (hot press) dengan suhu $165^{\circ} \mathrm{C}$ dan kuat tekan sebesar 150 kgf. Setelah dihasilkan plastik, plastik tersebut memasuki tahap keempat yaitu karakterisasi dengan analisis sifat mekanik berupa uji kuat tarik, analisis kemampuan terurai dengan uji biodegradable, dan analisis gugus fungsi dengan menggunakan FT-IR.

\section{HASIL DAN PEMBAHASAN}

\section{Analisis Sifat Mekanik dengan Uji Kekuatan Tarik dan Kemuluran}

Analisis sifat mekanik yang dilakukan adalah dengan menganalisis nilai kekuatan tarik dan kemuluran dengan acuan standar ASTM D - 1822 type $L$ dari variasi komposisi pengisi yang berbeda untuk menghasilkan plastik. Kekuatan tarik dan kemuluran merupakan faktor penting untuk menentukan sifat mekanik plastik yang diinginkan, dimana nilai kekuatan tarik diharapkan bernilai tinggi dan kemuluran yang tidak lebih dari 5\%. Hasil dari pengujian didapatkan nilai beban dan defleksi. Harga beban dan defleksi dihitung dengan menggunakan rumus :

$$
\text { Kekuatan Tarik }=\frac{P}{A \nu}=\frac{\text { Load }}{\Delta \omega}
$$

Ao $=$ tebal $\times$ lebar spesimen

Dimana $A o=0,1 \times 6 \mathrm{~mm}$

$$
\text { Ao }=0,6 \mathrm{~mm}^{2}
$$

$$
\begin{aligned}
\text { Kemuluran }(~) & =\frac{L t-L O}{L 0} \times 100 \% \\
& =\frac{\Delta L}{L 0} \times 100 \%
\end{aligned}
$$

Dimana $\Delta L=$ stroke

$$
\text { Lo }=64 \mathrm{~mm} \text { (lebar penampang sampel) }
$$

sehingga didapatkan nilai kuat tarik dan persentase kemuluran. Dari hasil penelitian ini, didapatkan data analisis kekuatan tarik dan kemuluran dari plastik biodegradable dari pati biji durian dan limbah plastik polipropilena dengan penambahan benzoil peroksida dan maleat anhidrida berbagai variasi komposisi massa 
(Tabel 1) dan hasil plastik biodegradable pada kondisi optimum (Gambar 1).

Dari data hasil karakterisasi sifat mekanik berupa uji tarik tersebut dapat dilihat nilai kekuatan tarik dari plastik yang dihasilkan akan menurun seiring dengan penambahan pati dan pengisi lainnya, sedangkan nilai kemuluran akan menurun. Nilai kekuatan tarik dan kemuluran akan berubah karena menurunnya sifat dasar dari polipropilena dengan adanya penambahan pati (Mariana 2007). Nilai kekuatan tarik yang tertinggi adalah pada plastik dengan komposisi limbah polipropilena, pati biji durian, maleat anhidrida (94:6:1) (C) dengan nilai kekuatan $13,407 \mathrm{~N} / \mathrm{m}^{2}$ dan nilai kemuluran $0,859 \%$. Perlu dipertimbangkan bahwa selain nilai kekuatan tarik yang tinggi, juga diperlukan persentase kemuluran yang rendah agar kekuatan plastik masih unggul, disamping itu juga perlu dipertimbangkan komposisi pengisi bahan plastik biodegradable yang digunakan dalam hal ini benzoil peroksida.

Benzoil peroksida digunakan sebagai inisiator yang memutus rantai panjang polipropilena untuk memudahkan proses grafting dengan maleat anhidrida sehingga dihasilkan plastik biodegradable yang campurannya homogen dan merata. Oleh karena itu, plastik biodegradable yang dihasilkan yang memiliki karakteristik yang diharapkan adalah plastik biodegradable dari limbah polipropilena, pati biji durian, maleat anhidrida, benzoil peroksida $(94: 6: 1: 1)$ (D) dengan nilai kekuatan tarik $9,81 \mathrm{~N} / \mathrm{m}^{2}$ dan kemuluran $0,5625 \%$.

Tabel 1. Hasil perhitungan kekuatan tarik dan kemuluran plastik biodegradable dari pati biji durian dan limbah plastik polipropilena dengan penambahan benzoil peroksida dan maleat anhidrida

\begin{tabular}{|c|c|c|c|c|}
\hline $\begin{array}{c}\text { Perbandingan } \\
\text { (komposisi dan massa) (\%) }\end{array}$ & $\begin{array}{c}\text { Beban } \\
(\mathrm{kgF})\end{array}$ & $\begin{array}{l}\text { Defleksi } \\
(\mathrm{mm})\end{array}$ & $\begin{array}{l}\text { Kuat Tarik } \\
(\sigma t)\left(\mathrm{N} / \mathrm{m}^{2}\right)\end{array}$ & $\begin{array}{l}\text { Kemuluran } \\
(\%)\end{array}$ \\
\hline Limbah plastik polipropilena (100) (A) & 1,7 & 3,50 & 27,2795 & 5,468 \\
\hline $\begin{array}{l}\text { Limbah polipropilena dan pati biji durian } \\
(94: 6)(B)\end{array}$ & 0,7 & 1,55 & 11,445 & 2,421 \\
\hline $\begin{array}{l}\text { Limbah polipropilena, pati biji durian, maleat } \\
\text { anhidrida }(94: 6: 1)(C)\end{array}$ & 0,82 & 0,55 & 13,407 & 0.859 \\
\hline $\begin{array}{l}\text { Limbah polipropilena, pati biji durian, maleat } \\
\text { anhidrida, benzoil peroksida (94:6:1:1) (D) }\end{array}$ & 0,6 & 0,36 & 9,81 & 0,5625 \\
\hline $\begin{array}{l}\text { Limbah polipropilena, pati biji durian, maleat } \\
\text { anhidrida, benzoil peroksida }(94: 6: 2: 1)(E)\end{array}$ & 0,3 & 0,75 & 4,905 & 1,171 \\
\hline $\begin{array}{l}\text { Limbah polipropilena, pati biji durian, maleat } \\
\text { anhidrida, benzoil peroksida }(94: 6: 3: 1)(\mathrm{F})\end{array}$ & 0,4 & 1,25 & 6,54 & 2,421 \\
\hline
\end{tabular}

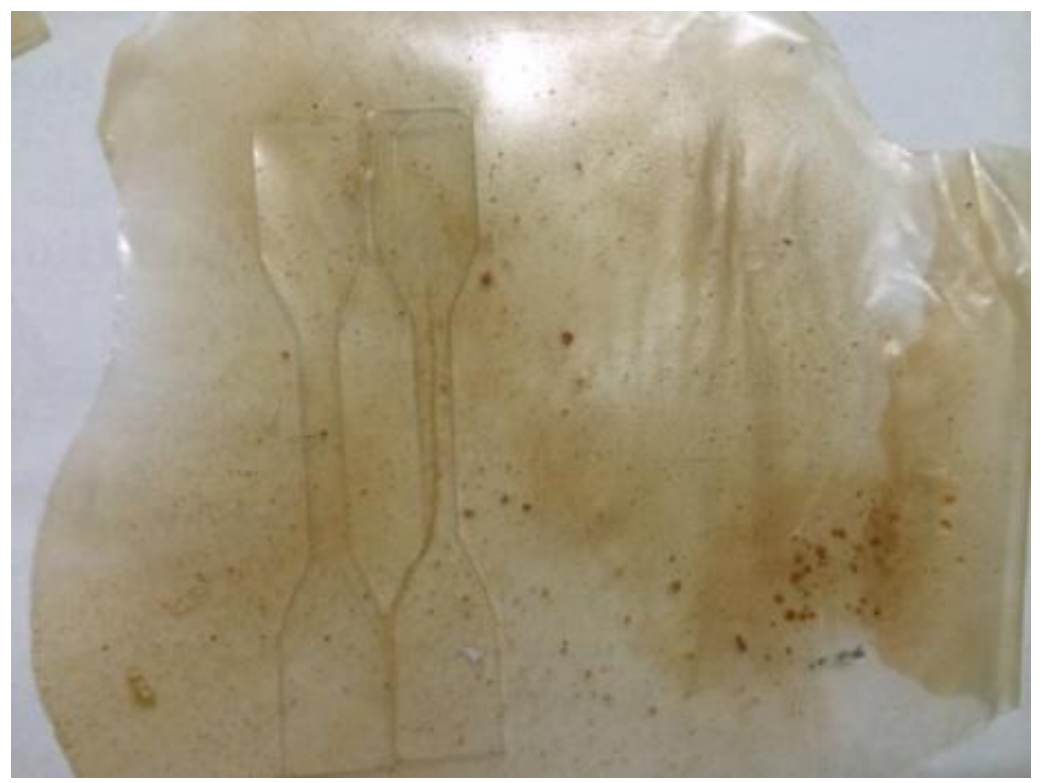

Gambar 1. Plastik biodegradable pada kondisi optimum 

Analisis Kemampuan Terurai di Alam dengan
Uji Biodegradable

Tahap utama degradasi adalah pemutusan rantai utama membentuk fragmen-fragmen dengan berat molekul rendah (oligomer) yang dapat diasimilasi oleh mikroba. Berdasarkan uraian tersebut, dapat dilihat degradasi secara penanaman lebih cepat karena semua faktor yang memicu terjadinya degradasi terdapat di lingkungan luar. Penurunan massa spesimen komposit kemasan plastik biodegradable sejalan dengan lamanya waktu penanaman.

Penguburan spesimen komposit biodegradable pada berbagai jenis tanah (tanah bakaran sampah, tanah kebun, dan tanah pasir) dengan pengamatan setiap 10 hari selama 1 bulan (Tabel 2) bertujuan untuk melihat tingkat kemampuan terurai di alam, hal ini karena salah satu tempat akhir kemasan plastik adalah kembali ke tanah. Pengujian sifat degradasi spesimen kemasan plastik biodegradable yang dihasilkan dilakukan secara pengomposan.

Dari data Tabel 2. data penurunan massa plastik biodegradable yang terurai di alam dengan uji biodegradable menunjukkan laju persentase biodegradasi dari kemasan biodegradable yang paling tinggi yakni pada kemasan plastik biodegradable dengan perbandingan limbah polipropilena, pati dari biji durian, maleat anhidrida, benzoil peroksida (94:6:1:1) yaitu pada tanah sampah sebesar $9,08 \%$. Harga penurunan plastik biodegradable yang terbesar adalah pada penanaman dalam tanah sampah, lalu tanah biasa, kemudian pasir. Hal ini mungkin disebabkan karena jumlah nutrisi dalam tanah sampah lebih banyak dibandingkan dengan tanah lainnya sehingga jumlah dan jenis mikrobanya juga lebih banyak. Mikroba yang membantu proses degradasi kemasan di dalam tanah adalah bakteri pseudomous dan bacillus yang memutus rantai polimer menjadi monomer masing-masing (Kaplan 2004). Penguburan spesimen dilakukan pada beberapa jenis tanah selama 30 hari dengan pengamatan setiap 10 hari dengan cara penimbangan.

Analisis Gugus Fungsi dengan Uji FT-IR (Fourier Transform Infrared Spectroscopy)

Analisis dengan menggunakan spektrum infra merah ini dilakukan untuk menentukan perubahan gugus fungsi dari limbah plastik polipropilena sebelum penambahan pengisi bahan alam (Gambar 2) dengan plastik biodegradable yang dihasilkan (Gambar 3).

Tabel 2. Data hasil penurunan massa (\%) spesimen plastik biodegradable setelah penanaman dalam tanah

\begin{tabular}{|c|c|c|c|c|c|c|c|}
\hline \multirow{2}{*}{$\begin{array}{c}\text { Variasi komposisi spesimen } \\
(\%)\end{array}$} & & \multirow{2}{*}{ Jenis tanah } & \multicolumn{4}{|c|}{ Penurunan massa spesimen setelah penanaman (gram) } & \multirow{2}{*}{$\begin{array}{l}\text { Penurunan } \\
\text { massa (\%) }\end{array}$} \\
\hline & & & Awal & 10 Hari & 20 Hari & 30 Hari & \\
\hline \multirow{3}{*}{ Limbah polipropilena (100) } & 1. & Tanah sampah & 1. 0,2381 & 1. 0,2381 & 1. 0,2360 & 1. 0,2355 & 1. 1,09 \\
\hline & 2. & Tanah biasa & 2. 0,2783 & 2. 0,2783 & 2. 0,2768 & 2. 0,2766 & 2. 0,61 \\
\hline & 3. & Pasir & 3. 0,2455 & 3. 0,2455 & 3. 0,2455 & 3. 0,2455 & 3. 0 \\
\hline \multirow{3}{*}{$\begin{array}{l}\text { Limbah polipropilena : PBD } \\
\qquad(94: 6)\end{array}$} & 1. & ampah & 1. 0,1964 & 1. 0,1960 & 1. 0,1952 & 1. 0,1945 & 1. 0,97 \\
\hline & 2. & Tanah biasa & 2. 0,1404 & 2. 0,1396 & 2. 0,1380 & 2. 0,1375 & 2. 2,06 \\
\hline & 3. & Pasir & 3. 0,2024 & 3. 0,2024 & 3. 0,2020 & 3. 0,2014 & 3. 0,49 \\
\hline \multirow{4}{*}{$\begin{array}{c}\text { Limbah polipropilena : PBD } \\
\text { : MA }(94: 6: 1)\end{array}$} & 1. & Tanah sampah & 1. 0,2375 & 1. 0,2365 & 1. 0,2357 & 1. 0,2354 & 1. 0,88 \\
\hline & 2. & Tanah biasa & 2. 0,2963 & 2. 0,2954 & 2. 0,2950 & 2. 0,2944 & 2. 0,65 \\
\hline & & Pasir & 3. 0,3271 & 3. 0,3268 & $3.0,3260$ & $3.0,3257$ & 3. 0,42 \\
\hline & 1. & Tanah sampah & 1. 0,2972 & 1. 0,2843 & 1. 0,2657 & 1. 0,2450 & 1. 9,08 \\
\hline \multirow{2}{*}{$\begin{array}{l}\text { Limbah polipropilena : PBD } \\
\text { : MA : BPO }(94: 6: 1: 1)\end{array}$} & 2. & Tanah biasa & 2. 0,3019 & 2. 0,2985 & 2. 0,2980 & 2. 0,2893 & 2. 4,17 \\
\hline & 3. & Pasir & 3. 0,2641 & 3. 0,2620 & 3. 0,2615 & 3. 0,2600 & 3. 1,55 \\
\hline \multirow{3}{*}{$\begin{array}{c}\text { Limbah polipropilena : PBD } \\
\text { : MA : BPO (94:6:2:1) }\end{array}$} & & Tanah sampah & 1. 0,2089 & 1. 0,2080 & 1. 0,2077 & 1. 0,2068 & 1. 1,01 \\
\hline & & Tanah biasa & 2. 0,2218 & 2. 0,2206 & 2. 0,2189 & 2. 0,2175 & 2. 1,93 \\
\hline & & Pasir & 3. 0,1930 & 3. 0,1925 & 3. 0,1923 & 3. 0,1920 & 3. 0,52 \\
\hline \multirow{3}{*}{$\begin{array}{l}\text { Limbah polipropilena : PBD } \\
\text { : MA : BPO }(94: 6: 3: 1)\end{array}$} & 1. & Tanah sampah & 1. 0,1456 & 1. 0,1450 & 1. 0,1438 & 1. 0,1427 & 1. 2,00 \\
\hline & 2. & Tanah biasa & 2. 0,2172 & 2. 0,2166 & 2. 0,2160 & 2. 0,2145 & 2. 1,24 \\
\hline & 3. & Pasir & 3. 0,2126 & 3. 0,2120 & 3. 0,2115 & 3. 0,2113 & 3. 0,61 \\
\hline
\end{tabular}


Terjadinya perubahan gugus fungsi yang dialami limbah polipropilena menandakan bahwa terjadi interaksi kimia antara limbah plastik polipropilena dengan bahan pengisi lainnya. Analisis dengan spektrum infra merah ini dilakukan dengan cara mengamati frekuensifrekuensi yang khas dari gugus fungsi spektra
FT-IR masing-masing sampel. Bilangan gelombang $F T$-IR limbah plastik polipropilena murni dan plastik biodegradable dengan perbandingan limbah polipropilena, pati biji durian, maleat anhidrida, benzoil peroksida (94:6:1:1) dapat dilihat pada Tabel 3

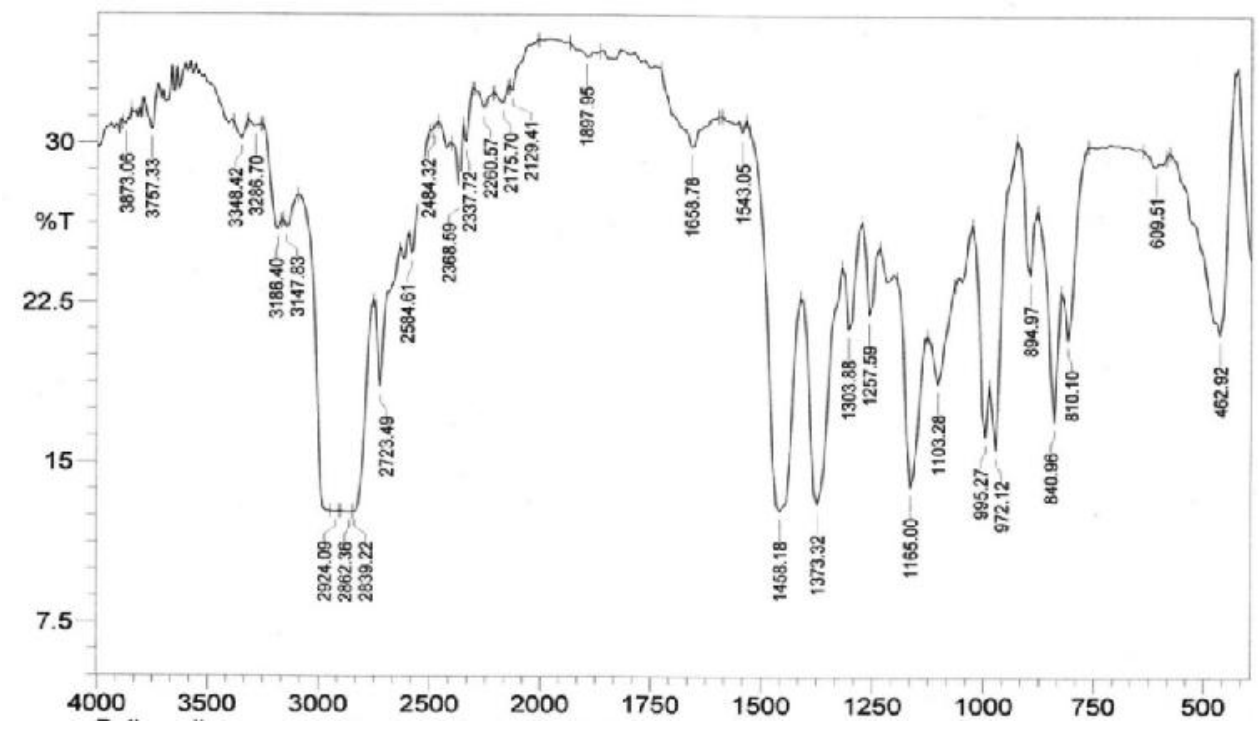

Gambar 2. Hasil spektrum FT-IR limbah plastik polipropilena sebelum penambahan pengisi

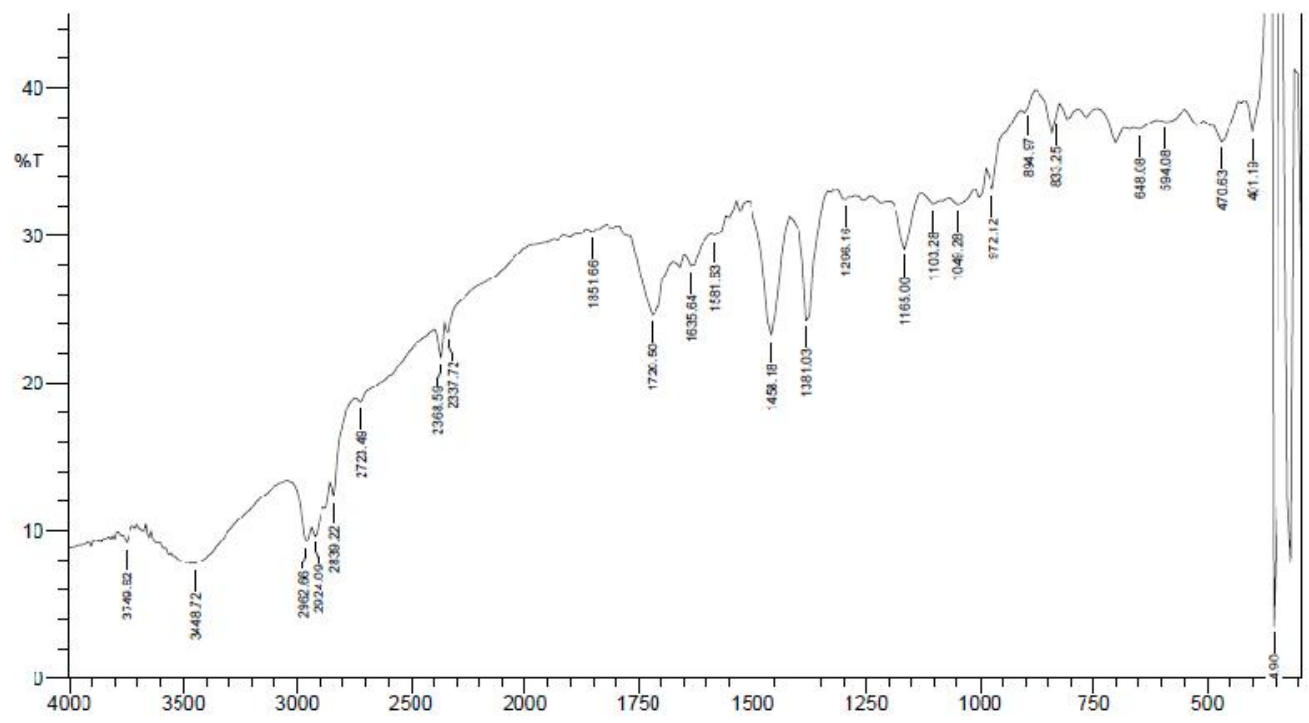

Gambar 3. Hasil spektrum FT-IR plastik biodegradable dengan perbandingan limbah polipropilena, pati biji durian, maleat anhidrida, benzoil peroksida (94:6:1:1) 
Tabel 3. Bilangan gelombang FT-IR

\begin{tabular}{lcc}
\hline \multicolumn{1}{c}{ Sampel } & Bilangan gelombang $\left(\mathrm{cm}^{-1}\right)$ & Gugus fungsi \\
\hline Limbah plastik polipropilena & 2924,09 & $\mathrm{CH}_{3}$ bending \\
& 2862,36 & $\mathrm{CH}_{2}$ bending \\
& 2723,49 & $\mathrm{C}-\mathrm{CH}_{3}$ bending \\
& 1458,18 & $\mathrm{C}-\mathrm{H}$ bending \\
Limbah polipropilena, pati biji durian, maleat & 1165,00 & $-\mathrm{CH}_{2}-\mathrm{CH}_{2^{-}}, \mathrm{CH}_{3}, \mathrm{CH}_{2}$ \\
anhidrida, benzoil peroksida (94:6:1:1) & 3448,72 & $\mathrm{O}-\mathrm{H}$ stretching \\
& 2839,22 & $\mathrm{CH}_{2}$ bending \\
& 2723,49 & $\mathrm{C}-\mathrm{CH}_{3}$ bending \\
& 1635,64 & $\mathrm{C}=\mathrm{C}$ stretching \\
& 1165,00 & $\mathrm{C}-\mathrm{O}$ bending \\
& 1458,18 & $\mathrm{CH}_{3}-\mathrm{CH}_{2}$ stretching \\
& 1381,03 & $\mathrm{CH}$ bending \\
& 849,97 & $\mathrm{C}-\mathrm{C}$ bending \\
& 1296,16 & $\mathrm{C}-\mathrm{O}$ stretching \\
& 1851,66 & $\mathrm{C}=\mathrm{O}$ stretching \\
\hline
\end{tabular}

Dapat dilihat pada bilangan gelombang $2924,09 \mathrm{~cm}^{-1}$ merupakan uluran $\mathrm{C}-\mathrm{H}$ dari gugus $\mathrm{CH}_{3}$ polipropilena dan bilangan gelombang $1165,00 \mathrm{~cm}^{-1}$ merupakan pita serapan gugus $-\mathrm{CH}_{2}-\mathrm{CH}_{2}-$ pada daerah sidik jari yang khas untuk polipropilena (Yunus 2011), bilangan gelombang yang menunjukkan gugus fungsi yang khas pada plastik biodegradable. Bilangan gelombang $1165,00 \mathrm{~cm}^{-1}$ yang menunjukkan gugus fungsi $\mathrm{C}-\mathrm{O}$ bending yang khas untuk menunjukkan ikatan antara limbah plastik polipropilena yang sudah grafting dengan maleat anhidrida dan pati yang didukung dengan bilangan gelombang $1635,64 \mathrm{~cm}^{-1}$ yang menunjukkan gugus fungsi $\mathrm{C}=\mathrm{C}$ pada maleat anhidrida dan polipropilena yang terikat silang. Selain itu terdapat beberapa gugus yang khas seperti pada limbah plastik polipropilena sebelum ditambahkan bahan pengisi, dan bilangan gelombang $3448,72 \mathrm{~cm}^{-1}$ yang menunjukkan gugus fungsi $\mathrm{O}-\mathrm{H}$ yang khas untuk menunjukkan pati.

\section{KESIMPULAN}

Telah dihasilkan plastik biodegradable yang dibuat dari campuran limbah polipropilena dengan pati biji durian, dengan penambahan maleat anhidrida sebagai agen pengikat silang dan benzoil peroksida sebagai inisiator. Kondisi optimum komposisi plastik biodegradable yang dihasilkan adalah pada perbandingan limbah polipropilena, pati biji durian, maleat anhidrida, benzoil peroksida (94:6:1:1). Berdasarkan hasil karakterisasi yang dilakukan dapat dilihat bahwa plastik biodegradable dapat tercampur merata antara limbah polipropilena dengan pati biji durian yang didukung dengan data kekuatan tarik $9,81 \mathrm{~N} / \mathrm{m}^{2}$ dan kemuluran $0,5625 \%$. Persentase penurunan massa plastik biodegradable yaitu sebesar 9,08\% pada tanah sampah dengan cara penanaman sampel selama 1 bulan. Plastik biodegradable yang dihasilkan berinteraksi secara ikatan kimia, dapat dilihat berdasarkan hasil analisis dengan menggunakan $F T$-IR yang menunjukkan bilangan gelombang yang khas untuk ikatan antara limbah polipropilena dan pati biji durian.

\section{DAFTAR PUSTAKA}

Djaeni, M., dan A. Prasetyaningrum. 2010. "Kelayakan Biji Durian sebagai Bahan Pangan Alternatif." RIPTEK 4 : 37-45.

Hidayani, T. R. 2012. "Pembuatan Komposit Biodegradabel dari Alpha Selulosa Ampas Tebu Bz 132 dan Polipropilena Tergrafting Maleat Anhidrida dan Divinil Benzena Sebagai Agen Pengikat Silang." Medan : Fakultas Matematika dan IImu Pengetahuan Alam, Universitas Sumatera Utara.

Hidayani, T. R., E. Pelita, dan D. Nirmala. 2015. "Karakteristik Plastik Biodegradabel Dari Limbah Plastik Polipropilena dan Pati Biji Durian." Majalah Kulit Karet dan Plastik 31 (1) : 12-19.

Inggaweni, L. dan Suyatno. 2015. "Karakterisasi Sifat Mekanik Plastik Biodegradable Dari Komposit High Density Polyethylene (HDPe) Dan Pati Kulit Singkong." In : Prosiding Seminar Nasional Kimia, 3-4.

Kaplan, D. L., J.M. Mayer, D. Ball, J. McCassie, A. L. Allen, dan P. Stenhouse. 2004. "Fundamentals of biodegradable polymers". In : Biodegradable Polymer and Packaging, 2074-2079.

Khoramnejadian, S. 2013. "Effect of Potato Starch on Thermal and Mechanical 
$\begin{array}{lcr}\begin{array}{l}\text { Properties of } \\ \text { Polyethylene." }\end{array} & \begin{array}{l}\text { Low } \\ \text { Current }\end{array} & \begin{array}{c}\text { Density } \\ \text { World }\end{array} \\ \text { Environment 8(2) : 215-220. } & & \end{array}$

Latief, R. 2011. "Teknologi Kemasan Plastik Biodegradabel”. Bandung : Makalah Falsafah Sains (PPs)

Mariana. 2007. "Beberapa Jenis Plastik yang Terbuat dari Plastik Daur Ulang". In : Prosiding Workshop on Food and Process Universitas Indonesia, 51-58.

Matondang, T. D. S. 2013. "Interaksi Kimia dari Pati Sagu Kelapa Sawit sebagai Pengisi pada Polipropilena Tergrafting Anhidrida Maleat dalam Pembuatan Bahan Plastik Kemasan Terbiodegradasikan." Jurnal Natur Indonesia 3 : $10-18$.

Ningsih, E. S. 2012. "Modifikasi Polipropilena Sebagai Polimer Komposit Biodegradabel Dengan Bahan Pengisi Pati Pisang dan Sorbitol Sebagai Plastisizer." Jurnal Fisika Unand 1 (1) : 209-214.
Nirmala, D., E. Pelita, dan T. R. Hidayani. 2014 "Interaksi Fisika Plastik Biodegradabel dari Limbah Polipropilen dengan Bahan Pengisi Pati Biji Durian." In : Laporan Penelitian ATIP.

Ummah, N. A. 2013. "Uji Ketahanan Biodegradable Plastic Berbasis Tepung Biji Durian (Durio Ziberhinus Murr) Terhadap Air dan Pengukuran Densitasnya." Semarang : Fakultas Matematika dan ilmu Pengetahuan Alam, Universitas Negeri Semarang.

Yuniarti. 2010. "Inventarisasi dan Karakterisasi Morfologis Tanaman Durian (Durio zibethinus Murr) di Kabupaten Tanah Datar." Jurnal Plasma Nutfah 2 : 1 - 6.

Yunus. 2011. "Fungsionalisasi Polipropilena Terdegradasi Menggunakan Benzoil Peroksida, Anhidrida Maleat dan Divinil Benzena Sebagai Bahan Perekat Papan Partikel Kayu Kelapa Sawit”. Medan: Fakultas Matematika dan ilmu Pengetahuan Alam, Universitas Sumatera Utara. 